\title{
IN MEMORY OF THE GREAT SCIENTIST JERZY OKULICZ-KOZARYN
}

'The patriotic feeling in society is cultivated not only through written and oral literature, but also though historical monuments that stand like silent witnesses of former glory and the suffering of the motherland. These are not dead ruins: they live on, preserving something of our ancestors that is mysteriously passed down to living generations. No palaces or houses in the most exquisitely decadent style can tell the stories that these silent ruins tell the soul.'

Nikolay F. Okulich-Kazarin (Николай Фомич Окулич-Казарин)

This quote comes from Nikolay F. Okulich-Kazarin, a man of the same lineage, a famous researcher into the antique culture of Pskov, who pronounced these words 98 years ago at a meeting of the Pskov Archaeological Society.

On 15 September 2012, the great European archaeologist Jerzy Okulicz-Kozaryn, a professor of modern Baltic archaeology at Warsaw, passed away, aged 81.

I had heard of this great researcher long before our first meeting. I had known about him since I read a monograph of his that appeared in 1973, entitled 'Prehistoric Prussian Lands from the Late Palaeolithic Period to the Seventh Century AD'. ${ }^{1}$ I was impressed by his knowledge, clarity and big ideas. For many years, this work served as a manual for researchers who were studying the eastern shores of the Baltic Sea, and it remains relevant even today.

To my deepest regret, I only met him quite late. Our acquaintance started in 2000, beginning with a very interesting conversation. I met him one beautiful autumn day in a small café by a lake during a conference in a place called Rybak of Masur in the Warmian-Masurian voivodeship in Poland. From the very first minutes of our conversation, his appearance and his manner of speaking were fascinating. I saw him more as an older relative than as a famous expert in archaeology.

It was very exciting to communicate with him, for he treated first-year students and great scientists on the same level. While I watched him talk with students, I always thought that communication between a teacher and his pupils should be like that. His circle of interests was not restricted to one area only, it was very wide. For example, he was always interested in what was happening in Kaliningrad. Apart from his other features, he had a great sense of humour and self-irony. I can remember one of his jokes: he mentioned once that one of his ancestors had been a Russian astronaut.

\footnotetext{
1 Pradzieje ziem pruskich od późnego paleolitu do VII w. n. e.. In Monografie dziejów społecznych i politycznych Warmii i Mazur, 1. Wrocław, Warszawa, Kraków, Gdańsk.
}

When someone expressed their astonishment, he went on, saying how Ivan the Terrible had shot one of his ancestors from a cannon. He was very fond of his family, and often talked about his father, Jaroslav OkuliczKozaryn, a pilot, an army officer and a First World War hero, a holder of the Order of St George, and a descendant of the Vitebsk nobility.

His distinguished career began with several problems. Despite his talent for and his great interest in history, Jerzy could not enter the university because of his 'unfavourable social background', which was quite in keeping with the spirit of the early 1950s. However, this obstacle did not make him give up. He chose another way, and started working at the Warsaw State Museum of Archaeology, which was his first 'university'. He studied archaeology there, and, apart from learning the basics of archaeological practice, and thanks to the access to libraries and cooperation with staff at the museum, he was also able to improve his skills as a theoretician.

He later managed to enter Warsaw University, and in 1955 he defended his MA dissertation. In the 1950s and 1960s, he was involved in the archaeological research of the Jotvingian Expedition. From 1962 to 1966, he began his own archaeological research in Northern Mazovia, as a candidate for a doctoral degree from the Polish Academy of Sciences Institute of History and Material Culture in Warsaw. As a result, in 1966 he successfully defended his thesis, which is considered a model, even today. In 1968, Jerzy started working at Warsaw University as a junior research assistant in the Department of Ancient and Early Medieval Archaeology. He obtained his doctoral degree in 1971. 


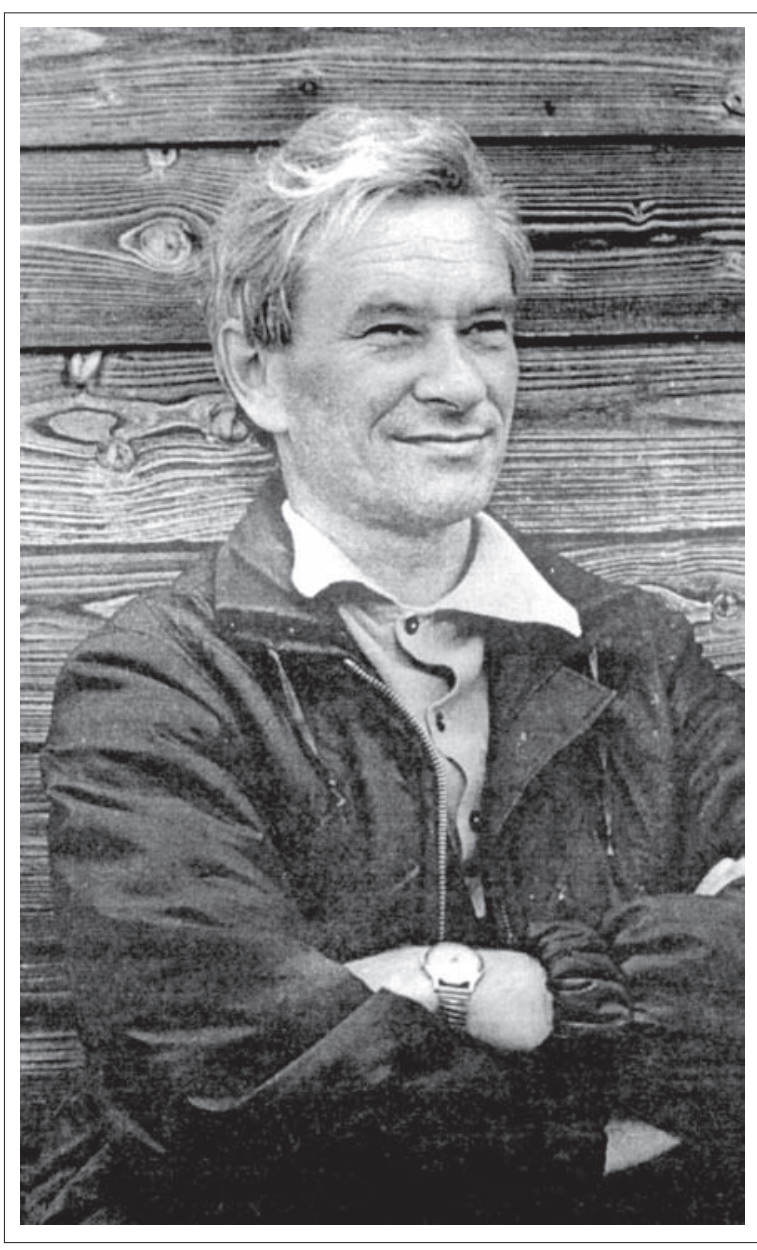

Jerzy Okulicz-Kozaryn (1931-2012)

He organised numerous archaeological expeditions in northeast Poland, often with his wife Lucia, with whom he created the perfect union. However, he never abandoned theory. In the Concordia collection that was published in 1996 to mark his anniversary, there were over 127 publications, including monographs. He wrote lots of works. He was the founder and the head of the Department of Ancient European Archaeology at the University of Warsaw, which dealt with the study of the Pre-Roman Period and the era of the Great Migration. He organised and managed scientific institutions dealing with ancient European archaeology, and he worked closely with the Polish Academy of Sciences. His postgraduate students joined the research departments of the Archaeological Institute in various parts of the country. He was the head of the Polish Scientific Society of Archaeologists from 1988 to 1991. In 1985, Jerzy Okulicz-Kozaryn became a professor, and in 1994 a full professor.

His careful research continued even after his retirement in 2001. In fact, it seemed that he was getting younger and stronger. Jerzy Okulicz-Kozaryn was an active participant in various symposia and conferences, at home and abroad. He organised several Baltic seminars that were held for over ten years at the State Archaeological Museum in Warsaw. He reviewed scientific papers, and participated regularly in teaching activities. He assisted research groups dealing with the processing and interpretation of material from several important historic monuments that are now considered crucial to Polish archaeology. These are the repository of Wielbark culture in Weklice, the West Balt Barrow culture burial site in Vyshembork, and the settlement complex in Shurpiles.

Today we can only envy the amazing energy and hard work of Jerzy Okulicz-Kozaryn, which he demonstrated over his entire life, remaining a great man, a good friend, and a wise teacher. I met him several times later: at the University of Warsaw and in his home, in Kaliningrad, and at various conferences and seminars. Every time I saw him, I felt his energy and optimism, feeling that if there are such people in the world, all will be well. It was amazing that age did not affect his spirit or his mind; his great achievements did not make him hard. His approach to research was always innovative and creative, he was an open, sincere and honest man. Jerzy could listen with interest to criticism, although his own opinion was always expressed delicately, in his aristocratic manner, in order not to offend anyone.

Jerzy Okulicz-Kozaryn was often called 'the master' by his numerous students and colleagues. I believe that this is the most fitting description. And despite the fact that he is no longer with us, he will live on in his legacy of numerous publications and students, and in our hearts and minds.

Konstantin N. Skvortsov 